\title{
Comparison of Speech Audiometry Using KS Word List and Hahm's List in Hearing Impaired Adults
}

\author{
Sung Hye Park ${ }^{1 *}$, Hyo-Jeong Lee ${ }^{1 *}$, Jina Kim ${ }^{1}$, Eunoak Kim, \\ Jung-Hak Lee ${ }^{2}$, and Hyung-Jong Kim ${ }^{1}$ \\ ${ }^{I}$ Department of Otorhinolaryngology-Head and Neck Surgery, Hallym University College of Medicine, Chuncheon; and \\ ${ }^{2}$ Department of Audiology, Hallym University of Graduate Studies, Seoul, Korea
}

\section{난청성인의 어음청력검사에서 한국표준 어음청력검사어표와 함태영어표의 비교}

박성혜 $^{{ }^{*}} \cdot$ 이효정 ${ }^{*} \cdot$ 김진아 ${ }^{1} \cdot$ 김은옥 $^{1} \cdot$ 이정학 $^{2} \cdot$ 김형종 $^{1}$

한림대학교 의과대학 이비인후-두경부외과학교실, ${ }^{1}$ 한림국제대학원대학교 청각학과 ${ }^{2}$

\author{
Received July 1, 2014 \\ Revised August 11, 2014 \\ Accepted August 19, 2014 \\ Address for correspondence \\ Hyung-Jong Kim, MD, PhD \\ Department of Otolaryngology, \\ Hallym University \\ Sacred Heart Hospital, \\ 22 Gwanpyeong-ro 170beon-gil, \\ Dongan-gu, Anyang 431-796, Korea \\ Tel $+82-31-380-3842$ \\ Fax $+82-31-386-3860$ \\ E-mail hjk1000@hallym.ac.kr \\ *Both contributed equally on this \\ work.
}

Background and Objectives The purpose of this study was to compare speech audiometry test results of the conventional Hahm's list with those of Korean standard word lists for adults (KS-WL-A) using both live voice and compact disc (CD) speech presentation modes.

Subjects and Method Eighty patients with sensorineural hearing loss and 23 control subjects with normal hearing participated in the study. Each hearing loss group comprised 20 subjects (mild, moderate, moderately severe, and severe hearing loss groups). Speech audiometry was performed to measure the speech recognition threshold (SRT) and word recognition score. KSWL-A was presented either through a live voice mode or recorded CD materials. Test words from Hahm's list were presented using the live voice mode only. Pure tone audiometry was also conducted for all subjects.

Results Differences between the SRT and pure tone average were within $6 \mathrm{~dB}$ in all subgroups in all three stimulation methods, indicating high reliability of the SRT in both the conventional and Korean standard methods. The moderate, moderately severe, and severe hearing loss groups showed lower word recognition scores in the CD mode with KS-WL-A than with the two live voice modes.

Conclusion Both the live voice mode and CD mode showed reliable speech audiometry test results in normal and hearing-impaired subjects. Although the CD mode is recommended to standardize test methods and reduce test errors, the live voice mode might be more effective for patients with moderate to severe hearing loss. Korean J Otorhinolaryngol-Head Neck Surg 2015;58(2):88-94

Key Words Speech audiometry $\cdot$ Speech discrimination tests $\cdot$ Speech reception threshold test.

\section{서 론}

국내에서 주로 사용되는 어음청력검사의 검사도구로는 기 존에 가장 널리 사용되어 온 함태영의 어음청력검사어표 ${ }^{1}$ 와 최근 지식경제부 표준화사업과제로 개발된 한국표준 어음청 력검사어표 ${ }^{2}$ 가 있다. 후자는 2009년 12월 지식경제부(현 산업
통상자원부) 국가기술표준원에 의해 한국산업표준(Korean Industrial Standards, KS)으로 채택되었고, ${ }^{3)}$ 국제적으로도 국 제표준화기구(International Organization for Standardization) 와 국제전기기술위원회(International Electrotechnical Commission)의 표준으로 등록되어 국제적으로도 대한민국의 표 준 어음청력검사도구로 인정받은 바 있다.,5) 이 검사어표는 후 
속된 연구에 의하여 어음청력검사의 검사도구로서 신뢰성을 확인한 바 있었고, ${ }^{6}$ 검사어 자극제시방법에 따른 검사결과를 비교한 연구도 보고되었으나, 실제 임상에서 적용해야 하는 검사대상인 난청환자에서의 연구보고는 드문 실정이다.

본 연구에서는 다양한 정도의 난청환자에서 첫째, 함태영 검사어표와 한국표준 검사어표를 사용하였을 때 검사어표 에 따른 검사결과의 차이가 있는지 알아보고자 하였으며 둘 째, 한국표준 검사어표를 사용할 때 실제 육성으로 단어를 제 시하는 육성법(live voice mode)과 컴팩트디스크(compact disc, $\mathrm{CD})$ 에 녹음된 목소리를 제시하는 녹음법(CD mode)을 이용 한 검사어 제시방법에 따른 검사결과의 차이가 있는지 비교 해보고자 하였다.

\section{대상 및 방법}

\section{연구 대상}

연구 대상은 만 18 세 이상의 성인으로 외이 및 중이 병변이 없는 정상청력군 23 명과 난청군 80 명으로 하였고, 난청군은 모 두 수평형(flat type, slope of 0 5 dB/octave) $)^{8)}$ 후천성 감각신 경성난청으로 정도에 따라 경도(26 40 dB HL), 중등도(41 55 $\mathrm{dB} \mathrm{HL})$, 중등고도(56 70 dB HL), 고도(71 90 dB HL) 난청 군마다 20명씩 포함하였고, 성별비는 남자 44명, 여자 59명이 었다. 평균연령은 정상군은 44세(19 76세), 청력손실군은 경 도 60세(28 77세), 중등도 67세(36 89세), 중등고도 59세 (30 81세), 고도는 60세(17 87세)였다. 각 군의 평균청력은 사 분법 $(0.5,1,2,3 \mathrm{kHz}$ 역치의 산술평균)을 사용하였을 때 정상 군의 순음청력역치평균(pure tone average, PTA)은 $11.43 \mathrm{~dB}$ $\mathrm{HL}$ 였고, 경도 $31.85 \mathrm{~dB} \mathrm{HL}$, 중등도 $50.30 \mathrm{~dB} \mathrm{HL}$, 중등고 도 $62.15 \mathrm{~dB} \mathrm{HL}$, 고도난청군은 $79.60 \mathrm{~dB} \mathrm{HL}$ 였다. 본 연구에 서는 연구대상을 보다 균질화하기 위해 선천성 난청과 전음성 난청은 대상에서 제외하였고, $90 \mathrm{~dB} \mathrm{HL}$ 이상의 심도 난청은 어 음청력검사 수행이 불가능하여 제외하였다. 본 연구는 한림대 성심병원 임상연구심의위원회의 승인을 받았다(2010-S052).

\section{검사 방법}

순음청력검사는 Grason Stadler(Eden Prairie, MN, USA) 사의 GSI 61 청력검사기를 사용하였고, 기도측정은 TDH-50P headphone(Telephonics, New York, NY, USA)을 사용하였 으며, 골도청력검사는 Radioear의 B-71 골도자극기(Radioear, New Eagle, PA, USA)를 사용하여 방음실(30 dBA 이하)에서 250 8000 Hz에 대하여 순음청력역치를 측정하였다.

어음청력검사는 어음인지역치(speech recognition threshold, $\mathrm{SRT}$ )와 단어인지도(word recognition score, WRS)를 측정하
였고, 검사도구로서 성인용 한국표준 이음절어표(Korean standards-bisyllabic word lists for adults, KS-BWL-A) 및 단음 절어표(Korean standards-monosyllabic word lists for adults, $\mathrm{KS}-\mathrm{MWL}-\mathrm{A})$ 와 함태영의 이음절어표 및 단음절어표를 사용 하였다(Table 1 and 2). ${ }^{9}$ 어음인지역치는 수정상승법(modified ascending method)을 사용하여 측정하였다. 즉, 피검자의 쾌 적수준(most comfortable level)에서 10개 단어 정도를 들려 주어 익숙하게 된 후에 사분법 순음청력역치평균에 $10 \mathrm{~dB}$ 을 더한 수준에서 시작하여 피검자가 정반응한 경우 $4 \mathrm{~dB}$ 하강 하고, 오반응한 경우 $2 \mathrm{~dB}$ 상승하여 $50 \%$ 득점하는 강도(3개의

Table 1. Bisyllabic words in KS-BWL-A $(2010)^{2)}$ and Hahm's list $(1962)^{9)}$ used in this study

\begin{tabular}{|c|c|c|c|c|c|}
\hline \multicolumn{3}{|c|}{ KS-BWL-A (2010) } & \multicolumn{3}{|c|}{$\begin{array}{c}\text { Hahm's bisyllabic } \\
\text { word list (1962) }\end{array}$} \\
\hline 편지 & 사람 & 그림 & 육군 & 필통 & 목욕 \\
\hline 달걀 & 토끼 & 아들 & 꽃병 & 송곳 & 엽서 \\
\hline 시간 & 병원 & 팥죽 & 독약 & 빛깔 & 방석 \\
\hline 육군 & 등대 & 동생 & 찰떡 & 극장 & 국수 \\
\hline 신발 & 논밭 & 목표 & 팥죽 & 톱밥 & 땅콩 \\
\hline 땅콩 & 과일 & 냄새 & 까치 & 뚜껑 & 색칠 \\
\hline 안개 & 송곳 & 바다 & 석탄 & 양복 & 달걀 \\
\hline 마음 & 딸기 & 자연 & 발톱 & 눈물 & 폭발 \\
\hline 허리 & 문제 & 접시 & 접시 & 책상 & 연필 \\
\hline 욕심 & 나무 & 권투 & 학생 & 합격 & 찹쌀 \\
\hline 노래 & 극장 & 방석 & 권투 & 딱총 & 욕심 \\
\hline 저녁 & 가위 & 느낌 & 약국 & 전차 & 콩팥 \\
\hline
\end{tabular}

Adapted from Lee, et al. ${ }^{2}$ Hakjisa;2010 and Hahm' Gunjn;1962

Table 2. Monosyllabic words in KS-MWL-A (2010)2) and Hahm's list $(1962)^{9)}$

\begin{tabular}{|c|c|c|c|c|c|}
\hline \multicolumn{3}{|c|}{ KS-BWL-A (2010) } & \multicolumn{3}{|c|}{$\begin{array}{l}\text { Hahm's monosyllabic } \\
\text { word list (1962) }\end{array}$} \\
\hline 귀 & 키 & 네 & 귀 & 배 & 뽕 \\
\hline 남 & 앞 & 벌 & 힘 & 침 & 되 \\
\hline 해 & 무 & 추 & 논 & 꿀 & 폭 \\
\hline 밀 & 논 & 만 & 맛 & 반 & 설 \\
\hline 옷 & 자 & 죄 & 솔 & 멋 & 뜻 \\
\hline 잔 & 글 & 일 & 잔 & 키 & 명 \\
\hline 댁 & 용 & 구 & 국 & 딸 & 은 \\
\hline 겁 & 겉 & 삼 & 솜 & 겁 & 북 \\
\hline 시 & 다 & 도 & 닭 & 향 & 점 \\
\hline 병 & 뜰 & 알 & 옆 & 법 & 밑 \\
\hline 소 & 피 & 胘 & 불 & 산 & 싹 \\
\hline 점 & 상 & 연 & 남 & 골 & 벼 \\
\hline 달 & 혀 & 녹 & 숫 & 집 & 왕 \\
\hline 덕 & 약 & 김 & 감 & 녹 & 색 \\
\hline 조 & 군 & 입 & 유天 & 끌 & 물 \\
\hline 폐 & 꿈 & 터 & 들 & 통 & 개 \\
\hline 샘 & 능 & & 잣 & 삼 & \\
\hline
\end{tabular}

Adapted from Lee, et al. ${ }^{2)}$ Hakjisa;2010 and Hahm ${ }^{9)}$ Gunjn;1962 
어음 중 2개)를 찾아 어음인지역치값을 구하였다. 단어인지도 는 순음청력역치평균을 기준으로 $40 \mathrm{~dB} \mathrm{SL}$ 에서 시행하며 50 개의 단음절 단어를 불러준 뒤 맞춘 개수를 \%로 나타내었다. 중고도나 고도 난청의 경우는 불쾌수준(uncomfortable loudness level)을 넘지 않는 범위에서 자극음의 강도를 결정하였 다. 한국표준검사어표는 검사자의 실제목소리로 음량계(volume unit meter, VU meter)를 보며 들려주는 육성법(live voice mode)과 사전에 컴팩트디스크에 녹음된 소리를 들려주는 녹 음법(CD mode)의 두 종류로 검사하였고, 함태영검사어표는 육성법만을 사용하여 검사하였다.

\section{통계 분석}

난청군별로 검사방법에 따라 차이가 있는지 확인하기 위해 반복측정 분산분석(Repeated measures ANOVA)을 어음인 지역치와 단어인지도에 대해 각각 시행하였다. 난청군별, 검사 방법에 의한 차이를 확인하고 난청군과 검사방법에 의한 차이 의 상호작용(interaction)을 분석하였으며, 사후분석으로 Tukey 의 방법을 사용하였다. 순음청력역치평균과 세 가지 자극방법 에 따른 어음인지역치 간의 상관관계 및 세 가지 자극방법에 따
른 단어인지도 간의 상관관계는 단순상관관계(simple correlation)로 분석하였다. 단순상관관계 분석은 모든 피험자를 포함하여 시행한 후, 각 난청군별로도 각각 시행하였다. 각 난 청군별로 어음인지역치와 순음청력역치평균의 차이의 절대값 이 6 보다 작은지 확인하기 위해 검정값을 6 혹은 -6 으로 설정 하여 단일표본 t검정(one sample t-test)을 시행하였다. 통계 프로그램은 MedCalc version 12.7.4.0(MedCalc Software, Ostend, Belgium)과 SPSS version 20.0(IBM, Armonk, NY, $\mathrm{USA}$ )을 사용하였고, 유의성 검정은 $p<0.05$ 수준으로 하였다.

\section{결 과}

\section{검사방법에 따른 어음인지역치의 비교}

세 가지 검사방법에 따른 어음인지역치와 순음청력역치평 균은 Table 3 과 같다. 반복측정 분산분석에서 난청군에 따 른 차이 $(p<0.001)$ 와 검사방법에 의한 차이 $(p=0.002)$ 는 유의 하였으나 난청군과 검사벙밥 간의 상호작용 $(p=0.394)$ 은 유의 미하지 않았다(Fig. 1). 사후분석으로 각 군별로 검사방법에 따른 어음인지역치의 평균을 비교하였을 때, 함태영이음절어

Table 3. Average of PTA and SRT according to the stimulation mode and degree of hearing loss (mean \pm s.d.)

\begin{tabular}{lcccc}
\hline $\begin{array}{c}\text { Degree of } \\
\text { hearing loss }\end{array}$ & PTA & $\begin{array}{c}\text { Hahm's bisyllabic word list } \\
\text { (live voice mode) }\end{array}$ & $\begin{array}{c}\text { KS-BWL-A } \\
\text { (live voice mode) }\end{array}$ & $\begin{array}{c}\text { KS-BWL-A } \\
\text { (CD mode) }\end{array}$ \\
\hline Normal & $11.4 \pm 8.2$ & $11.2 \pm 6.0$ & $10.0 \pm 6.7$ & $11.8 \pm 6.6$ \\
Mild & $31.9 \pm 4.0$ & $30.7 \pm 5.9$ & $29.9 \pm 5.9$ & $32.3 \pm 5.4$ \\
Moderate & $50.3 \pm 4.2$ & $51.8 \pm 5.8$ & $49.2 \pm 5.6$ & $52.6 \pm 5.2$ \\
Moderately severe & $62.2 \pm 3.5$ & $65.1 \pm 7.3$ & $62.6 \pm 6.2$ & $65.5 \pm 6.9$ \\
Severe & $79.6 \pm 5.6$ & $83.0 \pm 5.6$ & $80.6 \pm 6.1$ & $84.2 \pm 5.9$ \\
\hline
\end{tabular}

PTA: pure tone average, SRT: speech recognition threshold, s.d.: standard deviation, CD: compact disc, KS-BWL-A: Korean standards-bisyllabic word lists for adults

Fig. 1. Pure tone average (PTA) and speech recognition threshold (SRT) by three different measurements in different hearing groups. ${ }^{*} p<0.05$. KSBWL-A: Korean standards-bisyllabic word lists, CD: compact disc.

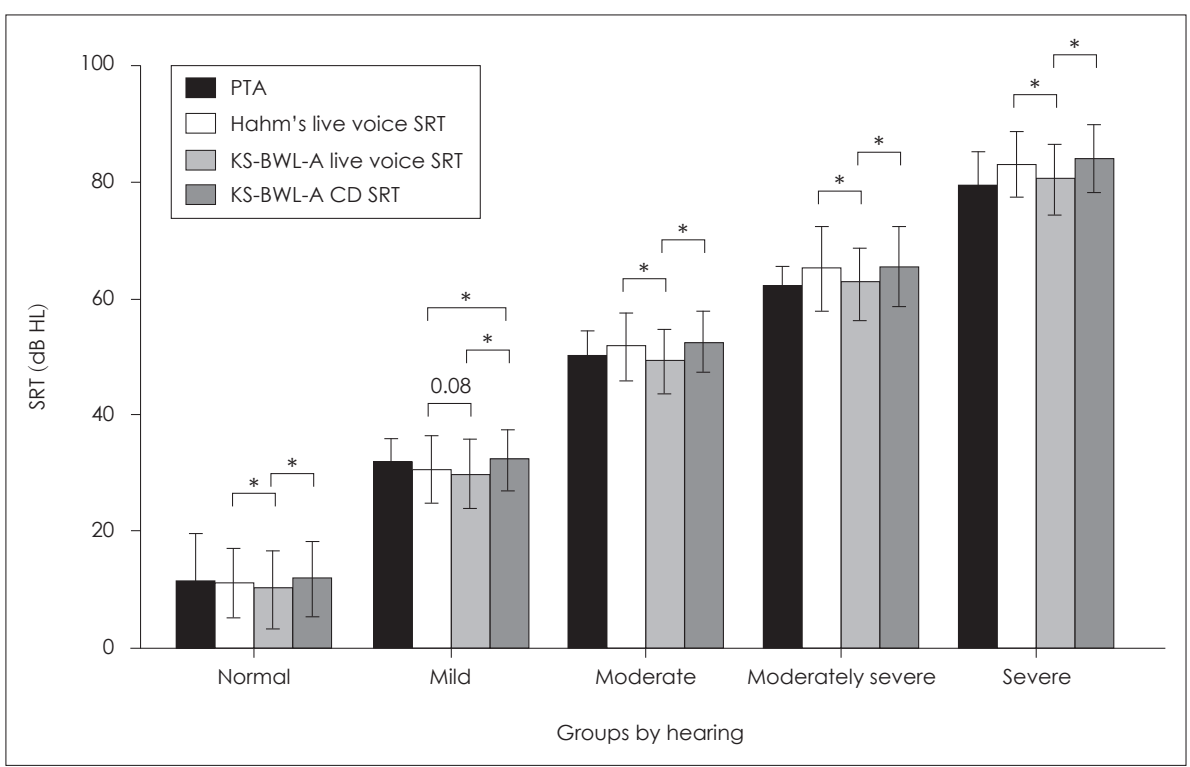


표의 육성법이 경도난청군을 제외하고 표준어표의 육성법보 다 높은 어음인지역치를 보였으며 $(p<0.05)$, 경도난청군에서 는 경계적 유의성 $(p=0.08)$ 을 보였다(Fig. 1). 함태영이음절어 표의 육성법은 표준어표의 녹음법보다 경도난청군에서는 유 의미하게 낮은 어음인지역치를 보였으나 $(p=0.02)$, 정상군과 다른 난청군에서는 모두 유의미하지 않은 차이를 보였다. 표 준어표의 육성법은 녹음법에 비하여 모든 난청군에서 유의 미하게 낮은 어음인지역치를 보였다 $(p<0.05)$ (Fig. 1).

검사방법에 따른 검사신뢰도를 알아보기 위해 어음인지역 치와 순음청력역치평균의 차이를 비교하였을 때(Fig. 2), 세 가 지 검사방법에서 모두 차이의 평균이 $\pm 6 \mathrm{~dB}$ 이내였다. 고도 난청군에서 표준어표의 녹음법을 사용한 경우 순음청력역치 평균과 어음인지역치의 차이의 평균값이 4.6(표준편차 5.6)으

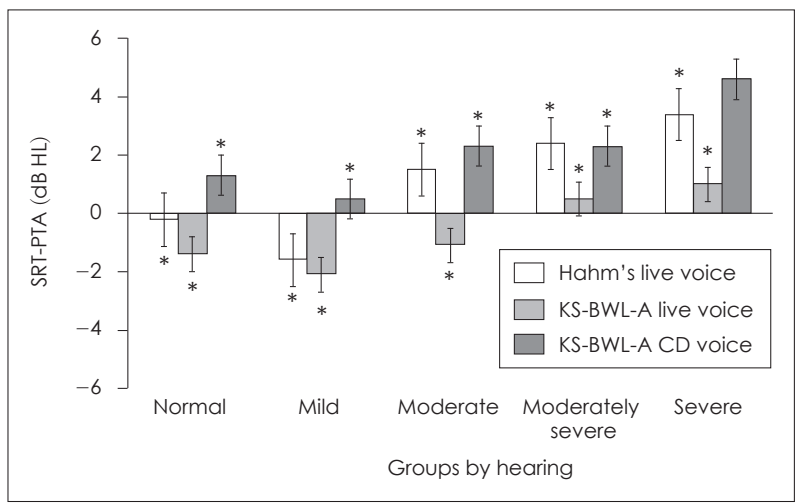

Fig. 2. Difference between PTA and SRT by three different measurements. *the absolute value of the difference mean is significantly smaller than $6(p<0.05)$. PTA: pure tone average, SRT: speech recognition threshold, KS-BWL-A: Korean standards-bisyllabic word lists for adults, CD: compact disc.
로 6보다 유의미하게 작지 않았으며 $(p=0.250)$, 그 외 다른 난 청군과 다른 검사방법에서는 모두 유의미하게 6보다 절대값 이 작은 값을 나타내어 신뢰성 있는 결과를 보였다.

각각 다른 검사방법을 사용한 어음인지역치가 순음청력역 치평균과 어느 정도의 상관성을 갖는지 알아보기 위해 상관 분석을 시행하였다(Table 4, Fig. 3). 순음청력역치평균과 함태 영이음절어표의 육성법(Fig. $3 \mathrm{~A}$ ), KS-BWL-A의 육성법(Fig. $3 \mathrm{~B}), \mathrm{KS}-\mathrm{BWL}-\mathrm{A}$ 의 녹음법(Fig. $3 \mathrm{C}$ )으로 측정된 세 가지 어음 인지역치와의 상관계수는 세 가지 모두 상관계수 0.9 이상의 매우 강한 양의 상관관계를 보였으며, 정상군, 경도군, 중등 도군, 중등고도군 및 고도난청군으로 나누어 분석하였을 때 에도 모두 상관계수 0.5 이상으로 통계적으로 유의한 $(p<0.05)$ 중등도 이상의 상관관계를 나타내었다(Table 4).

\section{검사방법에 따른 단어인지도의 비교}

세 가지 검사방법에 따른 단어인지도의 평균값은 Table 5 와 같다(Table 5, Fig. 4), 순음청력역치평균과 단어인지도는 세 가지 검사방법에서 모두 강한 음의 상관관계를 보였다(함 태영어표 육성법: $\mathrm{r}=-0.866, p<0.001$; KS-MWL-A 육성법: $\mathrm{r}=-0.852, p<0.001$; KS-MWL-A 녹음법: $\mathrm{r}=-0.883, p<$ 0.001).

반복측정 분산분석에서 난청군에 따른 차이 $(p<0.001)$ 와 검사방법에 의한 차이 $(p<0.001)$ 는 모두 유의하였고 난청군과 검사방법 간의 상호작용 $(p<0.001)$ 또한 유의미하였다. 사후 검정으로 각 군별 측정방법에 따른 단어인지도의 평균을 비 교하였을 때, 정상청력군과 경도난청군에서는 세 가지 검사법

Table 4. Correlation coefficients ( $p$-value) between PTA and SRT measured by 3 test methods in groups with different degree of hearing loss

\begin{tabular}{lccc}
\hline \multicolumn{1}{c}{ Degree of hearing loss } & Hahm's list (live voice mode) & KS-BWL-A (live voice mode) & KS-BWL-A $($ CD mode) \\
\hline Normal & $0.816(<0.001)$ & $0.811(<0.001)$ & $0.841(<0.001)$ \\
Mild & $0.826(<0.001)$ & $0.846(<0.001)$ & $0.792(<0.001)$ \\
Moderate & $0.578(0.008)$ & $0.506(0.023)$ & $0.628(0.003)$ \\
Moderately severe & $0.777(<0.001)$ & $0.836(<0.001)$ & $0.720(<0.001)$ \\
Severe & $0.699(<0.001)$ & $0.670(0.001)$ & $0.577(0.008)$ \\
\hline All subjects & $0.985(<0.001)$ & $0.986(<0.001)$ & $0.985(<0.001)$ \\
\hline
\end{tabular}

PTA: pure-tone average, SRT: speech recognition threshold, KS-BWL-A: Korean standards-bisyllabic word lists for adults, CD: compact disc

Table 5. WRS according to three stimulation methods and degree of hearing loss (mean \pm s.d.)

\begin{tabular}{lccc}
\hline \multicolumn{1}{c}{ Degree of hearing loss } & $\begin{array}{c}\text { Hahm's monosyllabic word list } \\
\text { (live voice mode) }\end{array}$ & KS-MWL-A (live voice mode) & KS-MWL-A (CD mode) \\
\hline Normal & $99.8 \pm 0.8$ & $99.7 \pm 1.7$ & $99.8 \pm 0.8$ \\
Mild & $98.0 \pm 5.7$ & $98.8 \pm 3.9$ & $98.2 \pm 6.4$ \\
Moderate & $69.3 \pm 18.1$ & $72.8 \pm 18.7$ & $59.0 \pm 21.9$ \\
Moderately severe & $45.2 \pm 24.4$ & $46.2 \pm 24.7$ & $39.7 \pm 23.2$ \\
Severe & $16.7 \pm 12.1$ & $18.8 \pm 16.4$ & $12.4 \pm 8.1$ \\
\hline
\end{tabular}

WRS: word recognition score, s.d.: standard deviation, CD: compact disc, KS-BWL-A: Korean standards-bisyllabic word lists for adults 
에 따른 차이가 유의미하지 않았으나, 중등도 이상의 난청을 가진 세 군에서는 표준어표의 녹음법에 의한 단어인지도가 다 른 두 가지 측정방법에 의한 결과보다 유의하게 작은 값을 보 였다(Fig. 4). 세 가지 검사방법에 따른 어음인지도 간의 상관
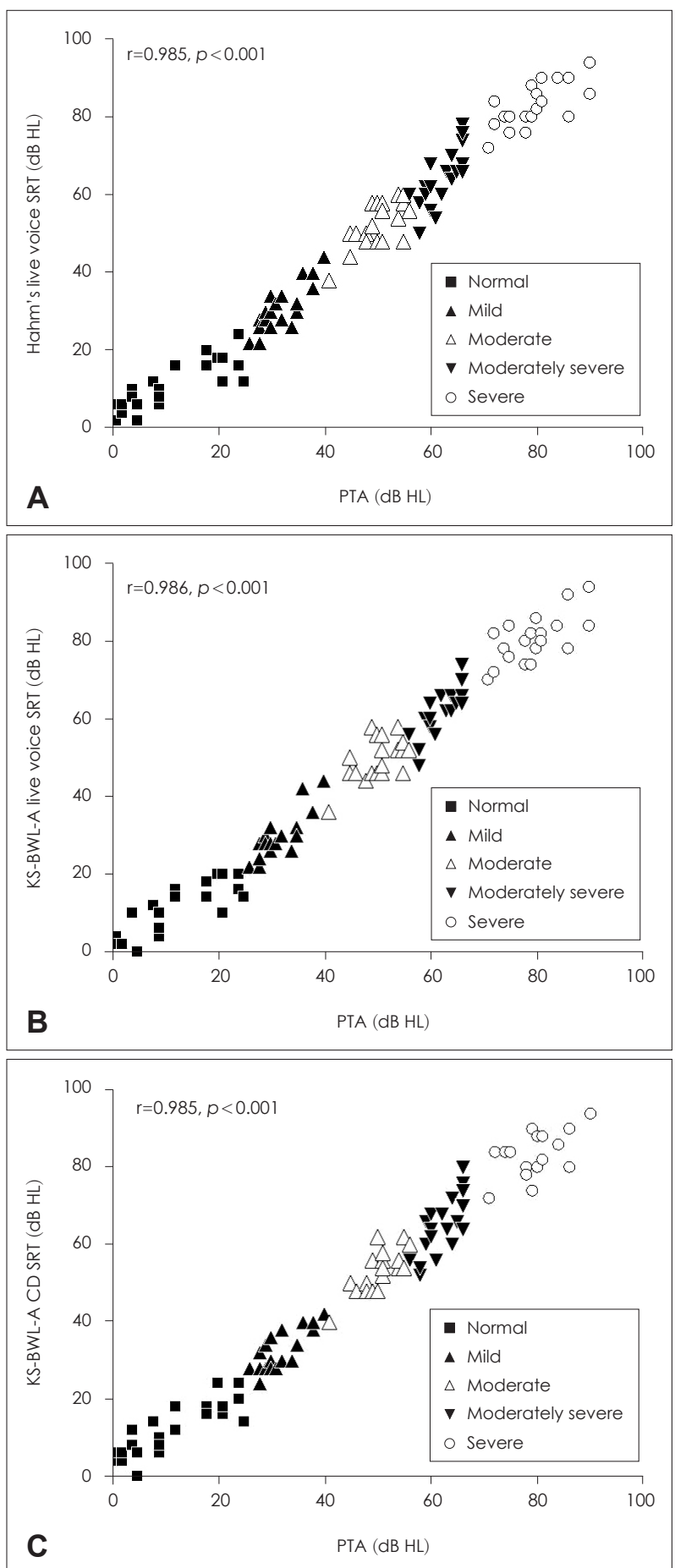

Fig. 3. Correlation between PTA and SRT by Hahm's live voice mode (A), KS-BWL-A live voice mode (B), and KS-BWL-A CD mode (C). PTA: pure-tone average, SRT: speech recognition threshold, KS-BWL-A: Korean standards-bisyllabic word lists for adults, CD: compact disc.
관계를 분석하였을 때, 전체 피험자에서는 상관계수가 모두 0.9 이상으로 매우 강한 상관관계를 보였다(Table 6, Fig. 5). 또 난청군별로 나누어 상관관계를 분석하였을 때에도 어음 인지도의 변이가 거의 없는 정상군을 제외하고는 모든 난청 군에서 모두 상관계수가 0.7 이상으로 세 가지 방법에 의한 어 음인지도 간에 통계적으로 유의하고 $(p<0.05)$ 강한 상관관계 를 보였다.

\section{고 찰}

한국표준 어음청력검사어표의 신뢰성을 확인한 이전의 연구 에서는 정상군 12 명(24귀)과 난청군 11 명(22귀)을 대상으로 어 음인지역치와 순음청력역치 평균을 구하였고, 26 64 dB HL 범위의 감각신경성 난청환자군에서 어음인지역치를 육성법 으로 측정하였을 때, 정상군과 난청군 모두에서 한국표준어 표를 이용한 어음인지역치가 함태영어표를 이용한 어음인지 역치보다 낮은 결과를 보였다. ${ }^{6)}$ 본 연구에서도 이와 동일한 결과를 확인할 수 있었는데(Fig. 1), 본 연구는 난청군을 좀 더 세분화하여 검사하였고, 동시에 이전의 연구에서 하지 못했던 육성법과 녹음법의 어음인지역치 차이에 대한 연구를 추가적 으로 실시했다는 점에서 보완된 연구결과라고 할 수 있다.

이전에 정상성인 14 명과 난청성인 18 명의 자극제시 방법에 따른 어음인지역치를 비교한 연구에서는 정상인에서는 육성 법과 녹음법으로 측정한 어음인지역치 결과에 차이가 없었 고, 난청성인에서 녹음법으로 측정한 어음인지역치가 육성법 으로 측정한 어음인지역치보다 약 $3 \mathrm{~dB}$ 더 낮게 나타났다고 하 였다. ${ }^{7)}$ 본 연구에서는 정상청력인 성인에서는 녹음법이 육성 법보다 어음인지역치가 평균 $2 \mathrm{~dB}$, 난청성인에서도 녹음법이 육성법보다 어음인지역치가 평균 $3 \mathrm{~dB}$ 높게 나타났다. 이는 연

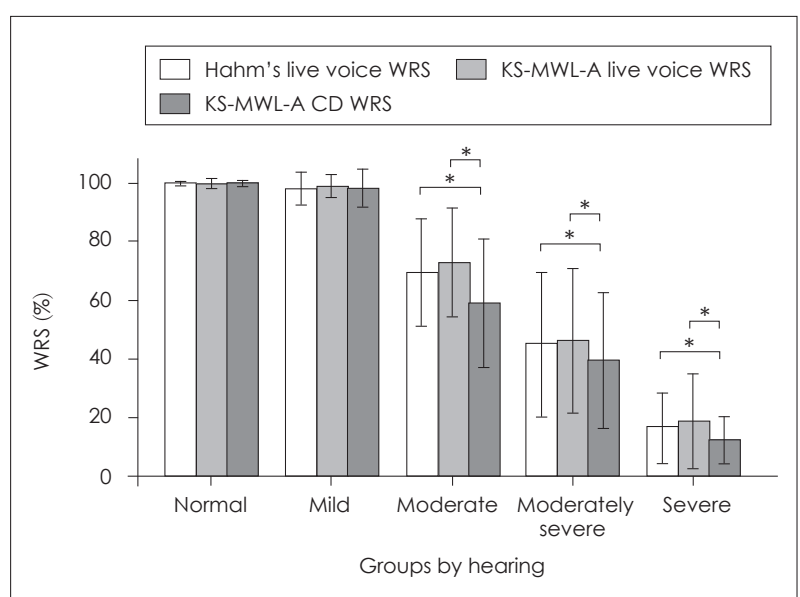

Fig. 4. Word recognition score (WRS) by three measurements in different hearing groups. ${ }^{*} p<0.05$. KS-MWL-A: Korean standardsmonosyllabic word lists for adults, CD: compact disc. 
Reliability of KS Word List for Speech Audiometry in Hearing-Impaired Patients I Park SH, et al.

Table 6. Correlation coefficients ( $p$-value) among WRS measured by 3 test methods in groups with different degree of hearing loss

\begin{tabular}{lccc}
\hline \multicolumn{1}{c}{ Degree of hearing loss } & $\begin{array}{c}\text { Hahm's list (live voice mode) } \\
\text { vs. }\end{array}$ & $\begin{array}{c}\text { KS-MWL-A (live voice mode) } \\
\text { vs. } \\
\text { KS-MWL-A (live voice mode) }\end{array}$ & $\begin{array}{c}\text { Hahm's list (live voice mode) } \\
\text { vs. }\end{array}$ \\
\hline Normal & $-0.045(0.837)$ & - & $-0.045(0.837)$ \\
Mild & $0.938(<0.001)$ & $0.982(<0.001)$ & $0.950(<0.001)$ \\
Moderate & $0.874(0.008)$ & $0.881(0.023)$ & $0.907(0.003)$ \\
Moderately severe & $0.943(<0.001)$ & $0.924(<0.001)$ & $0.908(<0.001)$ \\
Severe & $0.917(<0.001)$ & $0.786(0.001)$ & $0.846(0.008)$ \\
\hline All subjects & $0.983(<0.001)$ & $0.968(<0.001)$ & $0.978(<0.001)$
\end{tabular}

WRS: word recognition score, CD: compact disc, KS-MWL-A: Korean standards-monosyllabic word lists for adults

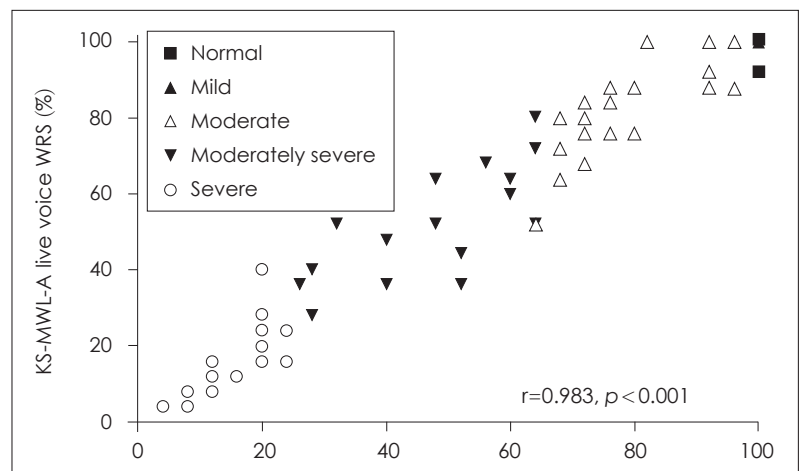

A Hahm's live voice WRS (\%)
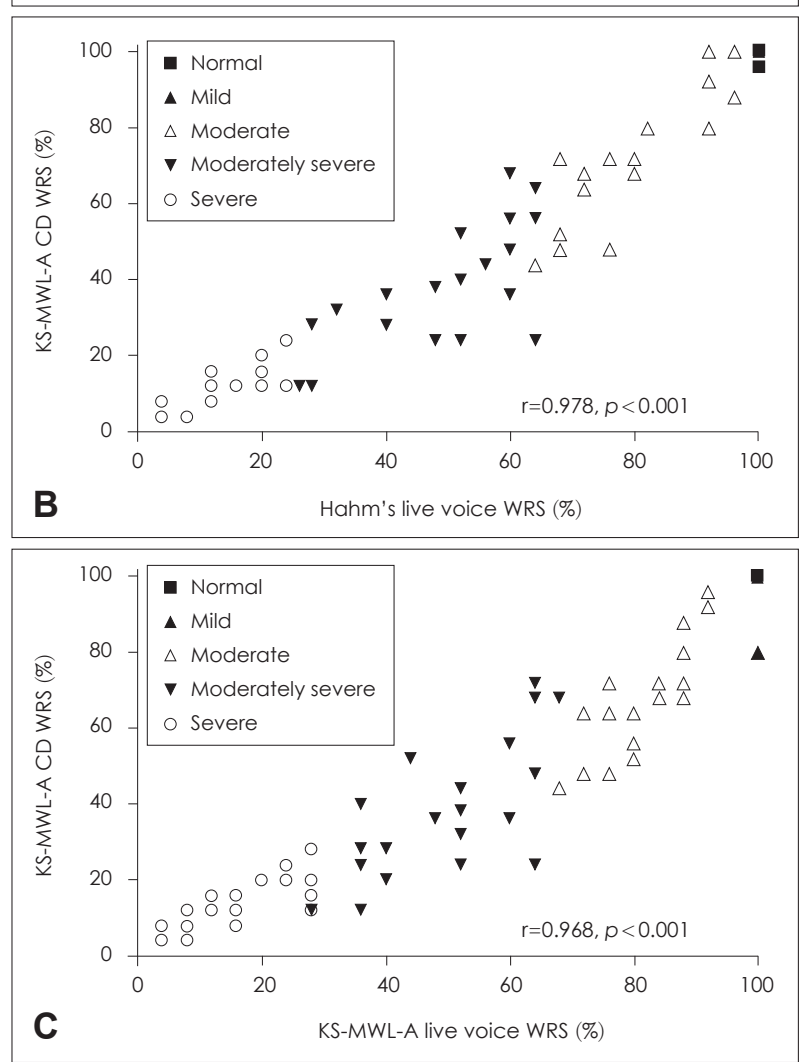

Fig. 5. Correlation among WRSs by three methods. Hahm's live voice mode versus KS-MWL-A live voice mode (A), Hahm's live voice mode versus KS-MWL-A CD mode (B), and KS-MWL-A live voice mode versus KS-MWL-A CD mode (C). WRS: word recognition score, KS-MWL-A: Korean standards-monosyllabic word lists for adults, CD: compact disc.
구방법상 정상성인과 난청성인의 연령, 집단의 수, 육성법에 서 검사자에 따른 차이가 검사결과에 영향을 미칠 수 있다고 판단된다. 본 연구에서 자극제시방법에 따른 검사 신뢰도 측 면에서 볼 때 어음인지역치와 순음청력역치평균의 차이가 $\pm 6 \mathrm{~dB}$ 이내이므로 정상성인과 난청성인 모두에게 육성법과 녹음법으로 측정된 어음인지역치 검사의 신뢰도가 우수한 것 으로 해석할 수 있다. ${ }^{10)}$ 단, 고도난청환자에서 표준어표의 녹 음법을 사용한 경우 순음청력역치평균과 어음인지역치의 차이 가 6보다 유의하게 작지 않아, 어음청력검사에 어려움을 느 끼는 고도의 감각신경성난청 환자에서는 검사자가 피검자와 상호작용을 할 수 있는 육성법이 검사의 신뢰도를 높이는 방 법이 될 것으로 사료된다. 본 연구는 난청군을 정도에 따라 경 도, 중등도, 중등고도, 고도로 나누어 표준어표를 이용한 육 성법과 녹음법에 따른 어음인지역치 검사를 실시한 결과, 기존 의 함태영어표를 사용한 어음인지역치와 마찬가지로 모든 정 도의 난청군에서 순음청력역치평균과 높은 상관성을 보였다.

이전 연구에서 난청성인 20명을 대상으로 자극제시방법에 따라 육성법과 녹음법으로 나누어 어음인지도를 비교하였을 때 통계적으로 유의미한 차이를 보이지는 않았지만, 육성법 에서 녹음법보다 점수가 높았다. ${ }^{11)}$ 본 연구에서도 난청 정도에 따라 나누어 보았을 때, 중등도 이상의 난청환자군에서는 녹 음법보다 두 가지 육성법으로 측정한 단어인지도가 유의하게 높았다. 이는 검사자가 어음전달속도에 변화를 줄 수 있고, 검사자가 검사의 진행을 상황에 맞게 자유로이 조절할 수 있는 육성법의 장점으로 인한 것으로 보인다. ${ }^{12}$

본 연구에서 난청군의 경우 녹음법에서 어음인지역치가 더 높고, 단어인지도가 더 낮게 나온 것은 녹음법에서 육성법에 서처럼 환자의 상황에 맞추어 검사어를 사용할 수 있는 검사 의 유연성이 부족하기 때문이라고 할 수 있다. 그러나, 전체피 험자에서 분석하였을 때뿐 아니라 난청군별로 분석하였을 때 순음청력역치평균과 세 가지 자극제시방법에 따른 어음인 지역치의 상관성이 모두 높고, 세 가지 자극제시방법에 따른 단어인지도 간의 상관관계도 매우 강하여 세 가지 검사방법 모두 임상에서 사용할 수 있는 신뢰성 높은 검사라는 것을 시 
사한다.

육성법에서는 검사자의 음성이 항상 일정한 음질과 음향을 나타내야 하는 어려움이 있으며, 발음이 정확해야 하고, 마이 크의 사용이 익숙한 숙련된 검사자가 필요하며, 동일한 검사 자라도 상황에 따라 음질과 음향이 변화할 수 있고, 검사자가 다르면 음의 강약과 발음에 차이가 있을 수 있다는 단점이 있 어 검사결과에 영향을 줄 수 있다. ${ }^{13)}$ 그에 반해 녹음법은 어휘 를 구성하고 제시하는 방법이 일관적이고 자극강도를 일정하 게 나타낼 수 있기 때문에 피검자나 검사장소에 상관없이 똑 같이 적용되며 모든 피검자들이 동일한 방식으로 검사받기 때문에 검사자에 의한 오차를 줄일 수 있어 신뢰도 높은 검사 를 할 수 있다고 보고된 바 있다. ${ }^{14)}$ 결론적으로 정상청력성인 과 난청성인에게 녹음법과 육성법 모두 신뢰성 있는 어음청력 검사 방법이라고 할 수 있으나, 검사자의 오차를 줄인다는 측 면에서 표준화된 녹음법을 사용하는 것을 추천하는 것이 바 람직하다고 할 수 있다. 그러나 고도 난청과 같이 어음청력검 사 실시가 어려운 환자에서는 숙련된 검사자가 환자와 상호작 용을 할 수 있는 육성법이 검사의 신뢰도를 높이는 방법이다.

\section{Acknowledgments}

This work was supported by the National Research Foundation of Korea (NRF) grant funded by the Korean Government (NRF-20100004427) and Hallym University Research Fund 2013 (HURF-2013-12).

Audiologic terms used in the manuscript follows suggestions of 'Proposal of audiologic terminology standardization in Korea (Korean J Audiol 2009;13(2):116-27). ${ }^{15)}$

\section{REFERENCES}

1) Hahm TY. Complementary study on construction of Korean word lists for speech audiometry. J Inje Med Coll 1986;7(1):1-19.
2) Lee JH, Jo SJ, Kim JS, Jang HS, Lim DW, Lee KW. Korean Speech Audiometry. Seoul: Hakjisa;2010. p.7-34.

3) Korean Agency for Technology and Standards. Acoustics-Audiometric test methods-Part 3: speech audiometry. KSI ISO 8253-3. Seoul: KATS;2009. p.1-36.

4) International Organization for Standardization. Acoustics-Audiometric test methods-Part 3: Speech audiometry. ISO 8253-3. Geneva: ISO; 2012. p.23-39.

5) International Electrotechnical Commission. Audiometric equipmentpart 2: Equipment for speech audiometry. IEC/CD 60645-2. Geneva: IEC;2010. p.11-2.

6) Jina K, Lee JH, Lee HJ, Kim HJ. Reliability of speech recognition threshold test using the Korean standard bisyllabic word list for adults in comparison with conventional Hahm's list. Korean J Otorhinolaryngol-Head Neck Surg 2012;55(6):350-4

7) Jo SJ. Comparison of speech recognition threshold according to presentation methods with stimulus in normal-hearing and hearing impaired adults. J Rehabil Res 2010;14(3):1-17.

8) Noh H, Chang KH. Development of compact disks in speech audiometry and first stage verification for the new speech materials. Korean J Otorhinolaryngol-Head Neck Surg 2010;53(5):290-9.

9) Hahm TY. Word lists for speech audiometry and performances of speech discrimination tests. Gunjin;1962. p.38-41.

10) Brandy WT. Speech Audiometry. In: Katz J, editor. Handbook of Clinical Audiology. 5th ed. Philadelphia: Lippincott Williams \& Wilkins;2002. p.96-110.

11) Back HJ, Lee JH. Psychometric functions of the one-syllable word recognition with monitored live voice versus recorded presentation for hearing impaired adults. Audiology 2007;3:122-30.

12) Kim EO. Speech audiometry. In: Audiologist training education. Seoul: Korean Association of Audiology;2005. p.135-43.

13) Hong SA. Test-retest reliability of Speech Discrimination Test using the monosyllabic word lists [dissertation]. Gangwon: Hallym Univ.; 2002.

14) Guidelines for determining threshold level for speech. ASHA 1988; 30(3):85-9.

15) Kim HJ, Lee HJ. Proposal of audiologic terminology standardization in Korea. Korean J Audiol 2009;13(2):116-27. 